\title{
Literacy Culture to Support Eco-School Program
}

\author{
Syunu Trihantoyo, Patrisia Mayagustina Windawati \\ Universitas Negeri Surabaya \\ Surabaya, Indonesia \\ syunutrihantoyo@unesa.ac.id
}

\begin{abstract}
The purpose of this study was to analyze the implementation and aspects that support students' literacy culture in the implementation of eco-school programs of a particular school in Surabaya. Also, the analysis present how the school overcome the inhibiting cultural factors of students' literacy in supporting ecoschool programs. Data was analyzed using interactive model through a qualitative method [1] including data condensation, displaying data, and drawing/verifying conclusions. The results of this study show that (1) the implementation of the students' literacy culture in supporting eco-school programs was based on legitimacy and allocation of time, which is about 40 minutes for routine literacy activities, and (2) the aspects supporting the students' literacy culture are leaders' commitment on the programme, role of library, role of subjects of natural science and workshop of creating handcraft.
\end{abstract}

\section{Keywords - students literacy, eco school program}

\section{INTRODUCTION}

School has a function and a strategic role in overcoming the low interest in reading. These function and role are reflected in student literacy activities $[2,3]$. The growth of literacy culture is important because literacy is the basis of students to acquire knowledge, skills, and attitude formation. Cultural literacy needs to be applied to learning activities in schools. In addition, literacy is a mirror of the progress of a nation. One of the indicators of such progress is reflected from the intensity of community literacy. A synergistic world of education and government is the right way in literacy culture. Indonesian students, particularly, should be qualified and globally competitive because Indonesia requires the thinking of young intellectuals who are competent and able to compete on the world level.

Metaphors that become obstacles in education is still a lack of interest in reading. Especially reading habits can affect the academic performance [4]. This is caused by various factors, such as school library program in creating reading culture for students, government policy in developing citizen literacy awareness, and the existence of global threat like Asian Economic Community. Those factors could become threat to the low reading of student literacy that weakens global competition.

Efforts by Indonesian government by launching the "School Literacy Movement" aimed at increasing learners' interest in reading. This movement is one way to develop strategies and diplomacy to foster student manners and to develop life skills through literacy. In improving students' reading interest, schools have a major role to foster students' interest in reading as well as to realize literate graduates. This is realized through the learning and library functions that became the heart of the school in building a culture of literacy [5].

Activities required to read all the books other than the subject books, which lasted for 15 minutes before the start of the learning activities have now been widely applied in Indonesian schools. It is regulated in the Regulation of the Minister of Education and Culture, which encourage the development about the culture of literacy. The presence of this regulation not only brings the spirit of character development, but also grows the unique and intact potential of student, and becomes a strategic step as well as the great hope of increasing the reading habit of Indonesian students.

Literacy (read-write) is an important thing that must be owned to advance the civilization of life. Learning from the history of great civilization, encouraging literacy can encourage the growth of new innovations in the development of science. For that, one way to build a scientific tradition in the school environment by optimizing the literacy among students. Encouraging literacy activities will make learners accustomed to critical thinking and doing a re-examination of the phenomena around them, and can establish their interest in reading and make students more adaptive [6]. In addition, literacy has a positive impact on students and society.

Previous research conducted by Sofa [7] found that the application of information literacy was observed in the writing of research projects conducted by students of Sekolah Alam Indonesia. In this project, students at grade 6 are required to make research report in a small scale as the product of writing project in accordance with the existing curriculum. They are not restrictited by the topic of research. Instead, they are free to choose the topic based on their own interest. They also get guidance from teachers so that teachers can monitor their progress in doing the project. The presentation is done after the research is completed. The purpose of this project is to support students' skill in experiencing writing activities independently although got little guidance from the teacher. Also, this is to foster the curiosity of students. Thus, students could think critically and could find answers to the research questions listed in the research project. Sofa [7] then found that students taking part in this writing project have gone through various processes of information literacy unconciously. The process run from choosing a topic, identifying the source of information, selecting information, processing information until presenting the research report. 
This study took SMPN 23 Surabaya, a state junior high school in Surabaya as the research background where culture of student literacy at that school became the research focus. Results of the initial study show that the school actually has unique school program which potentially support the literacy movement. The programs called "smart Friday, clean Friday, and health Friday", which started from year 2012, were carried out to oblige students to read books and make a summary of their reading. These activities became an initial step applied by the school.

The literacy culture in this school is very strategic in supporting the eco-school program. Cultural literacy brings a positive impact on the school academic achievement, such as winning various school library competitions $[8,9]$. Literacy activities can improve the ability to work more productively. The products produced by students related to eco-school activities include perfumes from leaves of ylang, ice from a banana peel, handmade processed from recycling waste, gardening, compost fertilizer from plant, and communication skill in presenting the products made. The implementation of literacy programmes also focused on the environment supporting 'greenhouse' movement such as developing hydroponics plants, garbage bank, and a plant area of strawberry. The activities of instilling a culture of reading and writing to students through such activities from an early age is an early manifestation in making educated societies.

\section{METHOD}

A qualitative method was used to interpret and analyze facts in the background of research applying case study research design. Key informants in this study were the principal of the school, while additional informants were the head of libraries, teachers of science subjects, teachers of Indonesian language subjects, and students. Data were collected through interviews, observation, and documentation. Data were analyzed by applying an interactive model that run continuously until the data is completely saturated [1]. Activities in data analysis include data condensation, display data, and conclusions drawing/verifying.

The research started from a preliminary study collecting information about the school. The information was used to determine the focus of research. Researchers arrange data collection instruments in accordance with the focus and data collection methods. The focus of this research is the implementation of student literacy culture in support of ecoschool programs and aspects that support the student literacy culture.

The next step is the collection of data in the background of research. The data collected is in the type of condensed data, which transforms the data closer to the entire section of field notes in writing, interview transcripts, documents, and other empirical materials. The condensed data was performed by displaying the data and drawing on conclusion. The overall stages of this study in accordance with the data analysis refer to Miles nd Huberman [1] and Sherman and Webb 10].

\section{RESULT AND DISCUSSION}

\section{A. Implementation of the Students' Literacy Culture in Supporting Eco-School Programs}

The implementation of literacy culture in supporting ecoschool programs is based on legal legitimacy. This can be seen from the vision and mission of the school, the decisions of the Mayor of Surabaya, and the policy of the Surabaya education office. Success in the implementation is seen from the achievement of the school in getting the award from the mayor of Surabaya as the winner of the Surabaya city level library.

In the effort to foster the development of culture of literacy in schools, the goal of literacy movement is to encourage students to have the character of reading and writing, caring and cultured character of the environment, as well as students who are literate and care about the environment [11]. In addition, there are efforts from external parties. They are supported by the policy of the education office and the mayor of Surabaya which mandating reading and compulsory reading curriculum programs. This was followed up by the socialization of the Surabaya literacy program instructed by the Surabaya education office to all the principals at all levels of education in Surabaya.

The implementation of literacy culture to support ecoschool program is very different regarding the addition of time allocation and how to implement it. The school allocated 40 minutes to read, while other schools allocated 15 minutes. This indicates that the school provides an in-depth focus on raising standards from established regulations. The literacy embryo of this school has evolved before the government launched a literacy program. Since 2012 the headmaster held 'clean Friday, health Friday, and smart Friday'. The 'smart Friday' activity is applied in a way that the students take turns, as the grade level is required to read the book and summarize the results of the reading each Friday in each month.

The 'Smart Friday' program is able to make students better to create ideas that exist in mind in the form of papers. The process of reading and writing habituation makes students literate. The literacy culture which has been implemented gives very satisfactory results, both in terms of quality of paper created by students and the process of literacy environment. This is evidenced by students who become more literate as they become more concerned about the environment as well as increase mental shaping and good character [12].

The eco-school activities resulting from the literacy culture include making biopori holes or rainfall absorption holes, making compost, hydroponic cultivation, and garbage banks. Those products were then sold and exhibited during an education bazaar. Through this event, the sttudents not only learn to read and write but also mental and good environmental care characters. Also, students have communication skills in presenting their work. This becomes an additional skill to increase the students' awareness of becoming an ecopreneur student [13-15].

A satisfactory achievement in the implementation of literacy culture is shaped by the commitment of all stakeholders. The success of the school is a portrait of the 
principal's spirit and the full support of external parties, including government [16]. School literacy movement is activity that is participatory involving all school members [17]. The seriousness of school can move all the school members to increase the interest of reading and make reading becomes a necessity of life.

The positive points from successful implementation of the literacy program are increasing students' understanding, practicing thinking skills, adding insight and knowledge, sharpening writing skills, supporting public speaking skills, improving concentration, increasing self-reflection and selfimprovement, changing ethical student character and courtesy, and faciltating students to produce some innovative products from the surrounding environment in the school [18, 19]. Thus, all such mentioned above are the forms of student literacy movement.

\section{B. Aspects that support the students' literacy culture}

The effectiveness and success of literacy program implementation are strongly influenced by several aspects. The most important aspect is the commitment of leaders and external parties interested in cultural literacy. Besides, the participation of all school members school can support the successful implementation of the cultural literacy program where all the major aspects have been described in the above discussion.

Second, the next aspects is the library and its supporting facilities, such as the availability of references about natural science, Indonesian language, and workshop of making handcraft. As per the research results, we found at least four components that support the school literacy program which have mutually supportive roles each other. The four components are described in detail as follows. First, the school library really became the heart of the school. The library is an important element in supporting the realization of literate and environmentally aware school members. The role of library is to support not only students' learning and student' literacy improvement, but also support the movement of becoming an eco school [20-22]. These all action are in line with the meaning of the slogan: "The Library as the Heart of Education". As the heart of the school, the role of library in shaping the human development index is very important and vital.

The role of the library is visible from the efforts of the library head to make the program called 'must visit the library and outdoor library'. This program attracts students to increase their habit of reading and writing. To support the program 'Surabaya Kota Literasi (Surabaya: Literacy city)', the school library is equipped with supporting facilities and infrastructures. The library also enables students by engaging directly in the 'library friends' program. The arrangement of the library also looks neat and clean, so that all the members of school are comfortable to visit. These efforts led to the increased reading and writing of students. In the end, the library held a contest which was followed by all students about the challenge of reading.

Secondly, the aspect that influences the culture of student literacy is the Indonesian language subject. This subject has a larger share among other subjects, due to the Indonesian language lesson which is directly related to literacy. Learning Indonesian language is also aimed at building a culture of literacy among students, especially learning activities that can improve the knowledge and skills of learners to read and write. Cultural literacy-based learning in education has advantages, such as not only improving students' capacity in understanding the discourse on a conservative basis, but also increasing students' active participation in applying social and intellectual understanding. Another role, the Indonesian language teacher in conducting the learning is to guide the students to select and prepare the study materials; examine the work of learners; directs the system to communicate science, and coordinate preparation of the class background for literacy activities [23]. In teaching, teachers also require students to visit the library and analyze actions which regards to environment. From this process, students look more guarded and preserve the environment. Students can develop what they learn so they can create simple technology. The products such as perfume from ylang-ylang flower, perfume with citronella fragrance, soap sarali, ice cream, recycled goods, and so forth are some examples of simple technology they created.

Third, the subject of natural science. These subjects contribute to the growth of literary culture, especially in ecoschool [24]. Students are asked to read the literature and learning about the surrounding environment. Student involvement in learning with the concept of learning by doing. This means students observe, ask questions, and identify the scientific things in the environment. This activity, for example, makes the question related to the scientific phenomenon of the material given by the teacher. Students' ability in identifying scientific phenomena is also done at the stage of collecting information or experiments. Students are required to formulate problems and practice hypotheses that are in accordance with the competencies contained in the lesson plans.

Fourth, the last aspect is the influence of workshop of making handcraft. The subject not only encouarge students to work on creating creative objects, students but also can foster students' literacy culture [25]. Regarding the relationship between the workshop and the literacy programme, the students are assigned to borrow the pre-packaged book according to their level of education. From the activity of reading a book related to making handcraft, students are asked to create the handcraft based on the tasks provided in the book they borrowed. Thus, the literacy activities would develop students' sense of curiosity and stimulate students' creativity. Through this workshop, the products of the student literacy culture emerged from students' activities which support ecoschool program includes clothes and hats made from plastic waste. Thus, the knowledge and skills the students acquired from this workshop can be useful for the students' awareness of surrounding environment.

\section{CONCLUSION}

The culture of literacy programme which supports ecoschool program in SMPN 23 Surabaya is aimed to foster students' reading interest, student literacy culture, as well as a solution to answer the low level of reading interest of 
Indonesian society. The implementation of the school for the literacy programme is by applying 'Smart Friday' and a firm commitment from the principal and external parties who have an interest in the realization of literary culture in schools. The aspects influencing the success of school literacy programme in that school include the role of library and its supporting facilities, subjects of natural science, subjects of Indonesian language, as well as subjects in the field of study workshop of making handcraft. Overall, the aspects has synergize in optimizing students in having reading habits and applying their reading habits to be useful from their surrounding environment.

\section{REFERENCES}

[1] M. B. Miles, A. M. Huberman, and J. Saldana, "Qualitative data analysis: A method sourcebook," CA, US: Sage Publications, 2014.

[2] K. H. Au, "Social constructivism and the school literacy learning of students of diverse backgrounds," Journal of literacy research, vol. 30, pp. 297-319, 1998

[3] R. Wharton-McDonald, M. Pressley, and J. M. Hampston, "Literacy instruction in nine first-grade classrooms: Teacher characteristics and student achievement," The Elementary School Journal, vol. 99, pp. 101-128, 1998.

[4] M. Owusu-Acheaw and A. G. Larson, "Reading habits among students and its effect on academic performance: A study of students of Koforidua Polytechnic," Library Philosophy and Practice, p. 0_1, 2014.

[5] R. Atkinson, "Library functions, scholarly communication, and the foundation of the digital library: Laying claim to the control zone," The Library Quarterly, vol. 66, pp. 239-265, 1996.

[6] M. Feuerstein, "Media literacy in support of critical thinking," Journal of Educational Media, vol. 24, pp. 43-54, 1999.

[7] N. Sofa, "Penerapan Literasi Informasi di Sekolah Alam Indonesia Rawa Kopi," Ilmu Perpustakaan, Universitas Indonesia, Depok, 2010.

[8] R. J. Todd, "The Power of Information Literacy: Unity of Education and Resources for the 21st Century," 1992.

[9] T. Paul, D. VanderZee, T. Rue, and S. Swanson, "Impact of the Accelerated Reader Technology-Based Literacy Program on Overall Academic Achievement and School Attendance," 1996.

[10] R. R. Sherman and R. B. Webb, Qualitative research in education: Focus and methods vol. 3: Psychology Press, 1988.
[11] W. J. Bennett, "Moral literacy and the formation of character," NASSP Bulletin, vol. 72, pp. 29-34, 1988

[12] E. A. Wynne and H. J. Walberg, "Character Building: Transmitting Values in Schools," Curriculum Review, vol. 26, pp. 18-22, 1986.

[13] K. Nuringsih and I. Puspitowati, "Determinants of Eco Entrepreneurial Intention Among Students: Study in the Entrepreneurial Education Practices," Advanced Science Letters, vol. 23, pp. 7281-7284, 2017.

[14] R. L. Lubis, "GREEN" E-PROJECT": THE 4-R SURVEY OF STUDENTS'ECOPRENEURSHIP," International Journal of Arts \& Sciences, vol. 6, p. 181, 2013.

[15] T. McEwen, "What, why, and how of ecopreneurship: Implications for entrepreneurship education," in Allied Academies International Conference. Academy of Entrepreneurship. Proceedings, 2012, p. 33.

[16] C. Ansell and A. Gash, "Collaborative governance in theory and practice," Journal of public administration research and theory, vol. 18, pp. 543-571, 2008

[17] D. Loertscher and B. Woolls, "The Information Literacy Movement of the School Library Field: A Preliminary Summary of the Research," 1997.

[18] W. Drakeford, "The impact of an intensive program to increase the literacy skills of youth confined to juvenile corrections," Journal of Correctional Education, pp. 139-144, 2002.

[19] K. W. Malmgren and P. E. Leone, "Effects of a short-term auxiliary reading program on the reading skills of incarcerated youth," Education and Treatment of Children, pp. 239-247, 2000.

[20] K. C. Lance, "The Impact of School Library Media Centers on Academic Achievement," 1992.

[21] K. C. Lance, M. J. Rodney, and C. Hamilton-Pennell, "How School Librarians Help Kids Achieve Standards: The Second Colorado Study," 2000.

[22] K. C. Lance, M. J. Rodney, and C. Hamilton-Pennell, "Measuring Up to Standards: The Impact of School Library Programs \& Information Literacy in Pennsylvania Schools," 2000

[23] J. J. Stuppy, "System and method for conducting a learning session using teacher and student workbooks," ed: Google Patents, 2004.

[24] C. P. Casteel and B. A. Isom, "Reciprocal processes in science and literacy learning," The Reading Teacher, vol. 47, pp. 538-545, 1994

[25] J. Allen and K. Gonzalez, There's room for me here: Literacy workshop in the middle school: Stenhouse Publishers, 1998. 